Available online at GSC Online Press Directory

GSC Biological and Pharmaceutical Sciences

e-ISSN: 2581-3250, CODEN (USA): GBPSC2

Journal homepage: https://www.gsconlinepress.com/journals/gscbps

(RESEARCH ARTICLE)

\title{
Effects of organic and inorganic fertilizers on agro-morphological traits of tomato (Solanum lycopersicum (L.) Moench)
}

\author{
Abejide Dorcas Ropo *, Yakubu Daniel Ojochegbe, Iyeh Veronica Amina and Oguche Joyce Ugbojo-Ide \\ Department of Plant Science and Biotechnology, Kogi State University, Anyigba, Kogi State, Nigeria.
}

Publication history: Received on 21 April 2020; revised on 22 May 2020; accepted on 24 May 2020

Article DOI: https://doi.org/10.30574/gscbps.2020.11.2.0112

\begin{abstract}
In order to determine the effect of organic and in-organic Fertilizers on agro-morphological parameters of tomato (Solanum lycopersicum (L.) Moench), a field experiment was conducted between August to November 2019 at the Research Garden of Plant Science and Biotechnology Department, Kogi State University, Anyigba. The seeds were grown with four treatments: Poultry dung, N.P.K (15:15:15) fertilizer, Cow dung and the control group (without fertilizer). The treatments were arranged in Complete Randomized Design (CRD) with three replicates. The seeds were first sown in a nursery bed without fertilizer and later transplanted to ridges after four (4) weeks. Data generated were subjected to Analysis of Variance (ANOVA) and means with significant differences separated using Duncan Multiple Range Test (DMRT). The results showed that application of poultry dung as soil amendment significantly (at p<0.05) supported higher plant height and stem girth (all through the growth period examined), number of fruits (8.75 \pm 1.49$)$, fruit weight $(25.30 \pm 4.75 \mathrm{~g})$, fruit length $(6.60 \pm 0.31 \mathrm{~cm})$, fruit diameter $(1.93 \pm 0.38 \mathrm{~cm})$. There was no significant difference in number of petioles, number of leaves and number of seeds per plant for all the fertilizer treatments. The result obtained indicated superiority of poultry manure over NPK fertilizer and cow dung application on crops as soil amendment. For optimum growth and development and subsequent yield of tomato, poultry manure is recommended as soil amendment.
\end{abstract}

Keywords: Organic; Tomato; Fertilizer; Inorganic; Agro-morphological

\section{Introduction}

Tomato (Solanum lycopersicum (L.) Moench) is a shade loving perennial plant in the Solanaceae family. The plant though widely cultivated in the tropics, was believed to be domesticated originally from central and southern America by Christopher Columbus on his second voyage in 1498 [1].

Tomato was believed to have arrived West Africa through Portuguese traders that travelled across the continent from Egypt and Sudan. It is however clear that the tomato cultivars in the country were introduced, and no wild relatives have been reported according to [2]. Tomato is predominantly grown in Nigeria during the wet season but according to [3] its production in dry season is limited to some states where irrigation farming/Fadama is practiced.

The leaves are covered with trichomes which are usually prostrate with only the tips being erect [4]. The flowers according to [5] are borne on short granular pedicels. One flower is produced at each leaf axils and other flowers usually blooms six (6) to ten (10) weeks after planting continuously until the upper most flowers open [6]. Tomato is a fruit and not a vegetable according to [7], and the former was reported by him to be an oblong pubescent berry containing numerous small, oval and yellow, white, red brown or black seeds. According to [8] tomato needs soil temperature of $70^{\circ} \mathrm{F}$ to germinate well, it is a summer crop that does well under irrigation and does not withstand high soil salinity [9].

\footnotetext{
* Corresponding author: Abejide Dorcas Ropo
} 
According to [10], they are popular vegetables that provide good quality vitamin A and vitamin C. In Nigeria, tomato fruit is used in cooking soup (stew), also sometimes added to breads, including toast breads. In Greece the fruits are used in the production of cakes, and in Togo they are a main soup ingredient, they are also eaten with bread in France [8]. In addition to its popular use as sauce on salads, tomato seeds and fruits are used in the production of paints and lubricants [5]. The average nutritive value of tomato is 2.14 as compared to 0.90 for both eggplant and water melon [10]. Tomato is consumed in diverse ways as it contains lycopene which helps fight against cancer, kidney defects and has several other health benefits. It can be eaten raw and commonly used as ingredient in many sauces, salads and drinks.

Tomato is currently one of the most important fruit (vegetable) crop in West Africa, especially Nigeria, despite these nutritive values, a number of production constraints which includes diseases, pests and costly chemicals affects tomato production [11]. Also, soil fertility decline has been identified as a major contributor to low yield [12]. Soil organic amendments such as cow dung and poultry manure are valuable sources of plant nutrients [13]. Organic manure provides essential nutrients to crops when decomposed and also act as soil conditioners [14]. Most developing countries are trying to get rid of expensive chemical fertilizers by supplementing them with some organic-based sources. Both organic and inorganic fertilizers provide plants with the nutrients needed to grow healthy and strong. However, each contains different ingredients and supplies these nutrients in different ways. Fertilizers supplement the soil with macronutrients needed in large amounts: nitrogen, phosphorus and potassium. However, organic and inorganic fertilizers do so via different materials. Thus, the aim of this study is to evaluate the use of organic and inorganic fertilizers in growing tomato to improve the yield of tomato as it is an important fruit (vegetable) to man.

\section{Material and methods}

\subsection{Study area}

This study was carried out at the Department of Biological Sciences, Faculty of Natural sciences, Kogi State University, Anyigba located between latitude $7^{\circ}$ 27' - $7^{\circ} 31^{\prime}$ North of the equator and between longitude $7^{\circ} 09^{\prime}-7^{\circ} 12^{\prime}$ East of the Greenish Meridian at an altitude of 420 meters above sea level. The site is known with a suitable atmospheric condition, having an annual mean rainfall and temperature of $1250 \mathrm{~mm}$ and $25^{\circ} \mathrm{C}$ respectively. The vegetation is typical of derived savanna with a sandy soil [15]. All the plantings were done at the Research garden of Biological Sciences Department, Kogi State University, Anyigba.

\subsection{Sample collection}

Hybrid tomato seeds (Solanum lycopersicum) were obtained from Agricultural Development Project (ADP) Extension workers in Lokoja Kogi State. Cow dung and poultry dung (organic fertilizers) were collected from Animal farm of the Department of Animal Production, faculty of Agriculture, Kogi State University, Anyigba. The chemical fertilizer (N.P.K 15:15:15) used for this study were obtained from Anyigba market.

\subsection{Experimental design}

The seeds were grown with four treatments:

- Control

- Cow dung

- N.P.K

- Poultry dung

The seeds were first sown in a nursery bed without fertilizer and was later transplanted to ridges after four (4) weeks. The poultry and cow dung fertilizer were applied during transplanting by mixing them with the ridges before transplanting. The treatments were arranged in a Complete Randomized Design (CRD).

\subsection{Growth parameters determined}

\subsubsection{Plant height}

This was taken by finding the average for eight (8) selected plants from the control and plants grown with the three nutrient sources. The measurements were taken from the soil level to the tip of the terminal bud at 6weeks, 8weeks and 10weeks after planting. This was measured using thread and later read on a meter rule. 


\subsubsection{Number of leaves per Plant}

The number of leaves per plant at 6 weeks, 8 weeks and 10 weeks after planting were counted for eight (8) randomly selected plants from the different nutrient sources and control treatment. The averages were recorded for each treatment.

\subsubsection{Stem girth}

The stem girth of the plants were measured using thread round the stem at the soil level and read on a meter rule. The measurement was done for eight (8) randomly selected plants from the different nutrient sources and control treatment at 6 weeks, 8 weeks and 10 weeks after planting.

\subsubsection{Number of Petioles per Plant}

The number of petioles per plant at 6weeks, 8weeks and 10weeks after planting were counted for eight (8) randomly selected plants from different nutrient sources and control treatment. The averages were recorded for each treatment.

\subsection{Yield parameters determined}

\subsubsection{Number of Tomato Fruits}

This was done by counting the number of fruit per plant which was done by random selection of eight plants from control treatment and the three nutrient sources.

\subsubsection{Weight of fruits}

This was done by putting the fruit on a weighing balance and taking the record.

\subsubsection{Number of seeds}

This was done by removing the seeds from the fruit, dried and then counted.

\subsubsection{Fruit diameter/Length}

The fruit diameter/length of eight randomly selected fruits from control and three different nutrient sources were taken using thread and later read on a meter rule.

\subsection{Statistical analysis}

Data obtained in this study were analyzed using Analysis of Variance (ANOVA) (SPSS Program, version 20 SPSS Inc., Chicago, IL, USA for computer package) and means with significant differences separated using Duncan Multiple Range Test (DMRT). Values of P less than $0.05(\mathrm{p}<0.05)$ were taken as significant.

\section{Results and discussion}

Analysis of variance (ANOVA) revealed that the effect of different organic and inorganic fertilizer on tomato plant height and stem girth at 6 weeks was significantly different at $p<0.05$ but there was no significant difference in number of petioles and number of leaves (Table1). Plants given poultry manure were observed to have the highest plant height $(16.04 \mathrm{~cm})$ and stem girth $(1.53 \mathrm{~cm})$ followed by cow dung $(15.25 \mathrm{~cm}, 1.40 \mathrm{~cm})$. The lowest plant height was observed in the NPK fertilizer $(13.60 \mathrm{~cm})$ although it was not significantly different from the control $(13.89 \mathrm{~cm})$, while the lowest stem girth was observed in the control $(1.09 \mathrm{~cm})$. At week 8, Analysis of variance also showed that there were no significant difference in number of leaves and petioles of the tomato plant but there were significant differences in the plant height and stem girth of plants given different fertilizer nutrients. The highest plant height was observed in plants given poultry manure $(33.34 \mathrm{~cm})$ and it was significantly different from all other treatments while the lowest plant height was observed in the control and it was not significantly different from cow dung and NPK fertilizer (Table 2). For the stem girth the highest value was observed in poultry manure $(2.01 \mathrm{~cm})$ and it was significantly different from all other treatments. The lowest stem girth was observed in plants given NPK fertilizer $(1.56 \mathrm{~cm})$ although it was not significantly different from the control $(1.58 \mathrm{~cm})$. 
Table 1 Effect of different fertilizers on growth parameters of Tomato at 6 weeks after planting.

\begin{tabular}{lllll}
\hline Fertilizers & Plant height(cm) & Number of petioles & Stem girth(cm) & Number of leaves \\
\hline Control & $13.89 \pm 0.81^{\mathrm{c}}$ & $4.38 \pm 0.92$ & $1.09 \pm 0.11^{\mathrm{d}}$ & $48.13 \pm 10.07$ \\
Cow dung & $15.25 \pm 0.46^{\mathrm{b}}$ & $4.38 \pm 0.52$ & $1.40 \pm 0.13^{\mathrm{b}}$ & $48.13 \pm 5.69$ \\
Poultry & $16.04 \pm 0.65^{\mathrm{a}}$ & $4.50 \pm 0.93$ & $1.53 \pm 0.10^{\mathrm{a}}$ & $49.50 \pm 10.18$ \\
& $13.60 \pm 0.97^{\mathrm{c}}$ & $4.50 \pm 0.93$ & $1.28 \pm 0.10^{\mathrm{c}}$ & $49.50 \pm 10.18$ \\
NPK & & $\mathrm{ns}$ & & $\mathrm{ns}$
\end{tabular}

Values are means \pm standard deviation, values followed by different alphabet(s) in a column are significantly different at P< 0.05 tested by Duncan Multiple Range Test. ns: no significant difference

Also at ten weeks, there was significant difference in the plant height and stem girth but no significant difference in number of leaves and number of petioles although control treatment produced the highest number of leaves and petioles (Table 3). The highest plant height was observed in the plants given poultry treatment $(56.92 \mathrm{~cm})$ and it was significantly different from all other treatments. The least plant height was observed in the control (43.83 cm) (Table3). Poultry manure also produced the highest stem girth $(3.01 \mathrm{~cm})$ as there was no significant difference in stem girth between the other three remaining treatment.

Table 2 Effect of different fertilizers on growth parameters of Tomato at 8 weeks after planting.

\begin{tabular}{lllll}
\hline Fertilizers & Plant height(cm) & Number of petioles & Stem girth(cm) & Number of leaves \\
\hline Control & $26.10 \pm 3.89^{\mathrm{b}}$ & $7.00 \pm 1.07$ & $1.58 \pm 0.09^{\mathrm{bc}}$ & $77.00 \pm 11.76$ \\
Cow dung & $27.75 \pm 1.29^{\mathrm{b}}$ & $7.25 \pm 0.46$ & $1.73 \pm 0.21^{\mathrm{b}}$ & $79.75 \pm 5.09$ \\
Poultry & $33.34 \pm 3.99^{\mathrm{a}}$ & $7.50 \pm 0.53$ & $2.01 \pm 0.22^{\mathrm{a}}$ & $82.50 \pm 5.88$ \\
& $26.84 \pm 2.39^{\mathrm{b}}$ & $7.00 \pm 0.76$ & $1.56 \pm 0.07^{\mathrm{c}}$ & $77.00 \pm 8.31$ \\
NPK & & $\mathrm{ns}$ & & $\mathrm{ns}$
\end{tabular}

Values are means \pm standard deviation, values followed by different alphabet(s) in a column are significantly different at $\mathrm{P}<0.05$ tested by Duncan Multiple Range Test; ns: no significant difference

Table 3 Effect of different fertilizers on growth parameters of Tomato at 10 weeks after planting.

\begin{tabular}{lllll}
\hline Fertilizers & Plant height $\mathbf{( c m )}$ & Number of petioles & Stem girth(cm) & Number of leaves \\
\hline Control & $43.83 \pm 6.37^{\mathrm{b}}$ & $12.25 \pm 1.67$ & $1.89 \pm 0.16^{\mathrm{b}}$ & $134.75 \pm 18,36$ \\
Cow dung & $48.45 \pm 4.7^{\mathrm{b}}$ & $11.12 \pm 0.99$ & $2.16 \pm 0.36^{\mathrm{b}}$ & $122.37 \pm 10.90$ \\
Poultry & $56.92 \pm 4.31^{\mathrm{a}}$ & $11.62 \pm 1.30$ & $3.01 \pm 0.44^{\mathrm{a}}$ & $127.87 \pm 14.33$ \\
& $44.98 \pm 4.36^{\mathrm{b}}$ & $11.88 \pm 1.25$ & $1.90 \pm 0.18^{\mathrm{b}}$ & $130.62 \pm 13.71$ \\
NPK & & ns & & ns
\end{tabular}

Values are means \pm standard deviation, values followed by different alphabet(s) in a column are significantly different at P< 0.05 tested by Duncan Multiple Range Test; ns: no significant difference

The significant differences observed in the growth parameters of tomato such as plant height, number of leaves, number of petioles and stem girth could be attributed to the level of nutrients available for plant absorption in the different types of fertilizers used. The application of poultry manure as soil amendment provided macro and micronutrients essentially required by tomato. This result is in line with [16], who reported that the use of poultry manure alone or in combination with NPK 15-15-15 fertilizer increased tomato yield compared to the application of NPK 15-15-15 fertilizer. Also, the result is in agreement with [17] who reported higher growth parameter values with the application of poultry manure. [18] also found that poultry manure litters resulted in better growth and yield of tomato than NPK fertilizer and other type of fertilizers. This study showed that tomato plant significantly performed well under balanced and judicious application of poultry manure more than other fertilizers. 
For the yield parameters, analysis of variance showed that there was no significant difference in number of seeds per plant but there was significant differences in number of fruits per plant, fruit weight, fruit length and fruit diameter. Plants given poultry manure were observed to have the highest number of fruits per plant (8.75), heaviest fruit per plant $(25.30 \mathrm{~g})$, highest fruit length per plant $(6.60 \mathrm{~cm})$ and highest fruit diameter $(1.93 \mathrm{~cm})$ which was significantly different from all other treatments. The lowest fruit length was observed in the control treatment $(4.41 \mathrm{~cm})$ which was significantly different from what was obtained in the other treatments. The number of fruits per plant was significantly favoured by the application of poultry manure. This result could be attributed to the ability of organic fertilizer to stabilize plant growth and also improve growth and yield. This result agreed with [19] who reported that nutrients from mineral fertilizers enhanced the establishment of crops, while those from mineralization of organic manure promoted yield when both fertilizers were combined. The result is also in line with the findings of [20], who found out that the number of fruits and leaves of crop significantly increased with increase in the concentration of poultry manure. It also tallies with the findings of [21] who reported that tomato fruit weight increased with increasing concentration of manure when compared with the control.

Table 4 Effect of Different Fertilizers on Yield Parameters of Tomato.

\begin{tabular}{llllll}
\hline Fertilizer & Fruit number & Fruit weight(g) & Fruit Length(cm) & Seed number & Fruit diameter(cm) \\
\hline Control & $4.00 \pm 1.85^{\mathrm{b}}$ & $15.89 \pm 8.38^{\mathrm{b}}$ & $4.41 \pm 0.44^{\mathrm{c}}$ & $97.25 \pm 33.39$ & $1.388 \pm 0.45^{\mathrm{b}}$ \\
Cow dung & $4.88 \pm 1.13^{\mathrm{b}}$ & $18.15 \pm 5.67^{\mathrm{b}}$ & $5.64 \pm 0.88^{\mathrm{b}}$ & $85.25 \pm 17.62$ & $1.40 \pm 0.36^{\mathrm{b}}$ \\
Poultry & $8.75 \pm 1.49^{\mathrm{a}}$ & $25.30 \pm 4.75^{\mathrm{a}}$ & $6.60 \pm 0.31^{\mathrm{a}}$ & $100.75 \pm 17.93$ & $1.93 \pm 0.38^{\mathrm{a}}$ \\
NPK & $5.25 \pm 2.25^{\mathrm{b}}$ & $19.84 \pm 2.93^{\mathrm{ab}}$ & $5.93 \pm 0.50^{\mathrm{b}}$ & $93.38 \pm 22.41$ & $1.51 \pm 0.36^{\mathrm{b}}$ \\
\multicolumn{5}{c}{ ns } \\
Values are means \pm standard deviation, values followed by different alphabet(s) in a column are significantly different at P< 0.05 tested by Duncan
\end{tabular}

\section{Conclusion}

The study revealed that use of inorganic and organic fertilizer had better effects on growth and yield of tomato. Although, the problems associated with inorganic fertilizer such as; high cost of purchase, scarcity, leaching, volatilization, environmental unfriendliness etc. have made inorganic fertilizer to be largely not recommendable as compared with organic fertilizers which is more environment friendly. The results obtained indicated superiority of poultry manure over NPK fertilizer and cow dung manure application on crops as soil amendment for all parameters evaluated.

\section{Compliance with ethical standards}

\section{Acknowledgments}

The Authors wish to appreciate Agricultural Development Project Office Lokoja Kogi State for providing Hybrid tomato seeds used in the research. We also appreciate the Department of Plant Science and Biotechnology, Kogi State University, Anyigba for providing their experimental garden for the Research.

\section{Disclosure of conflict of interest}

There is no conflict of interest.

\section{References}

[1] Tindall ND. (1993). Vegetables in the Tropics. Macmillan education limited. Houndmills, Basingstole, Hamsphere RD Xs and London.

[2] Powell AL, Nguyen CV, Hill T, Cheng KL, Figueroa-Balderas R, Aktas H, Ashrafi H, Pons C, Fernandez-Munoz R, Vicente A, Lopez-Baltazar J, Barry CS, Liu Y, Chetelat R, Granell A, Van-Deynze A, Giovannoni JJ and Bennett AB. (2012). Uniform ripening encodes a Golden 2-like Transcription Factor Regulating Tomato Fruit Chloroplast Development. Science, 336 (6089), 1711-1715. 
[3] Opena RT, Gheni LS and Hanson P. (2001). Hybrid seed production in Tomato; sharihua, Taiwan: International cooperation guide, 512-527.

[4] Donnelly L. (2008). Killer Tomatoes. The East Hampon star. Tomato component. Field Handbook of International tropical Agricultural Sciences, 2, 306-308.

[5] Cheng SC and Qualset CO. (2007). Diversity in Tomato collection and stratification of germ plasma accessions in different diversity groups. General Research Crop Evolution, 45, 325-335.

[6] Hannan MM, Ahmed MB, Razvy MA and Karim R. (2007). Heterosis and Correlation of Yield and Yield Composition in Tomato. Eurasian Journal of Science Resource, 2, 46-150.

[7] Nakarah K. (2003). Anti-oxidative metabolites in rat's liver with ingested sesame. Journal of Agriculture and Food Chemistry, 5(6), 1666-1670.

[8] Gaskell M, Milcheli J and Kolke ST. (2000). Soil fertility management for organic crops, organic vegetable productions. California serial publishers, 5.

[9] Navarro JM, Flores P, Carvajal M, Cerda A and Martinez V. (2003). Tomato yield and quality as affected by Nitrogen sources and salinity. International Journal of Agronomy and Plant Production, 23, 249-256.

[10] Kumar N, Bhatt RP and Biswas VR. (2001). Heterosis, combining ability and genetics for vitamins C, total soluble solid yields in tomato (Solanum lycopersicum) at 1700M. Attitude Journal of Agricultural Sciences, 137, 71-75.

[11] Ahuja KL. (2006). Nutrition for developing countries 2nd edition. Oxford University press, London, 106.

[12] Ahuja KL. (2005). Experimental pharmacologist and toxicologist and Australian pharmaceutical science Association. Melbourne, Australia, 67-79.

[13] Takahashi T, Inagaki H, Fukushima T, Oishi T and Matsuno K. (2010). Increasing nitrate removal at low temperatures by incorporating organic matter into paddy fields. Soil Science Plant Nutrition, 56(1), 163-7.

[14] Makinde EA, Ayoola OT and Akande MO. (2007). Effects of organo-mineral fertilizer application on the growth and yield of egusi melon. Australian Journal of Basic and Applied Science, 1(1), 15-19.

[15] Ifatimehin 00, Ujoh F and Patrick E. (2014). Attributes of topographic mapping of a fast urbanizing area in Nigeria, using remote sensing and GIS. Journal of Scientific Research and Reports, 3(1), 170-184.

[16] Adekiya AO and Agbede TM. (2009). Growth and yield of tomato (Lycopersicum esculentum Mill) as influenced by poultry manure and NPK fertilizer. Emir Journal of Food Agriculture, 21(1), 10-20.

[17] Ojeniyi SO, Agbede TM and Adeyemo AJ. (2008). Effect of poultry manure on soil physical and chemical properties, growth and grain yield of sorghum in southwest, Nigeria. Eurasian Journal of Sustainable Agriculture, 2(1), 72-75.

[18] Agele SO. (2002). Growth and yield of tomato grown on degraded soil amended with organic wastes. Proceedings of the 35th Conference of the Agricultural Society of Nigeria; Sept 16-21; University of Agriculture, Abeokuta Nigeria, 78-86.

[19] Ayoola OT and Adeniyan ON. (2006). Influence of poultry manure and NPK fertilizer on yield and yield components of crops under different cropping systems in south west Nigeria. African Journal of Biotechnology, 5(15), 86-92.

[20] Agbede TM, Ojeniyi SO and Adeyemo AJ. (2008). Effect of poultry manure on soil physical and chemical properties, growth and grain yield of sorghum in southwest, Nigeria. Eurasian Journal of Sustainable Agriculture, 2(1), 72-77.

[21] Ghorbani RA, Koocheki, MJ, Jahan M and Asadi GA. (2008). Impact of organic amendments and compost extracts on tomato production and storability in agro ecological systems. Agronomic Sustainable Development, 28(2), 307-11.

\section{How to cite this article}

Abejide DR, Yakubu DO, Iyeh VA and Oguche JU. (2020). Effects of organic and inorganic fertilizers on agro-morhological traits of tomato (Solanum lycopersicum (L.) Moench). GSC Biological and Pharmaceutical Sciences, 11(02), 314-319. 